\title{
How much do the conventional parameters contribute to the biological toxicity of surface water in different types of villages?
}

Ying Shao, Yueting Fan, Yinjie Yang, Min Zhou, Tingting Li, Fang Fang, Chenchen Wang, Yanxue Jiang, Zhongli Chen and Jinsong Guo* (1)

\begin{abstract}
Background: In rural areas, the surface water quality is seriously threatened by pollution from agriculture, breeding, industrial and tourism activities. Even though many strategies and programs were launched for rural environment management, it is challenging to tackle the serious surface water pollution in villages. Since pollution status varies with the type of villages, there is no single parameter that defines environment quality completely. Until recently, most of rural surface water quality monitoring programs focus only on the conventional parameters, while can these conventional parameters reflect comprehensive status of water quality? To study how much the conventional parameters contribute to biological toxicity of surface water in villages, the in situ parameters of $\mathrm{pH}, \mathrm{DO}, \mathrm{EC}, \mathrm{ORP}$, laboratorial parameters of $\mathrm{COD}, \mathrm{TN}_{1} \mathrm{NO}_{3}{ }^{-}-\mathrm{N}_{1} \mathrm{NO}_{2}{ }^{-}-\mathrm{N}_{1} \mathrm{NH}_{4}{ }^{+}-\mathrm{N}, \mathrm{TP}$, and $\mathrm{PO}_{4}{ }^{3-}{ }^{-} \mathrm{P}$ and acute toxicity were analyzed for the surface water samples those were collected from six types of villages, named breeding, agricultural, handicraft, industrial, agricultural and breeding, and tourism. The correlation analysis was applied to establish the linkages and contributions of each parameter.
\end{abstract}

Results: The results showed that all detected surface waters were alkaline, and the concentration of TN and most of COD concentrations in all six types of villages were higher than the Class V limits specified in environmental quality standards for surface water (GB3838-2002). Pearson's correlation analysis showed that significantly positive correlations were found for the acute toxicity effects and laboratorial parameters of $\mathrm{NO}_{2}{ }^{-}{ }^{-} \mathrm{N}_{1} \mathrm{NH}_{4}{ }^{+}-\mathrm{N}$ and $\mathrm{PO}_{4}{ }^{3-}-\mathrm{P}$ in agricultural villages, and negative correlations were found for the acute toxicity effects and laboratorial parameters of TN and $\mathrm{NO}_{3}{ }^{-}-\mathrm{N}$. No significant correlation was observed in breeding villages and industrial villages.

Conclusion: The problems of nitrogen pollution and aerobic pollution are still serious in villages, and more attention should be paid in further rural environment management. $\mathrm{NH}_{4}{ }^{+}-\mathrm{N}$ could contribute to the acute toxicity of surface water in the most of investigated villages, while no significant correlation was observed between acute toxicity and conventional parameters in industrial villages and tourism villages. Environmental monitoring programs focusing just on the classical conventional parameters are far from sufficient, since the main toxic contributors are quite different in diverse villages. The outcomes of the present study contribute to demonstrate the performance and usefulness of bioanalytical techniques for water quality assessment.

Keywords: Rural surface water, Conventional parameter monitoring, Bioanalytical techniques, Acute toxicity

*Correspondence: guo0768@cqu.edu.cn

Key Laboratory of the Three Gorges Reservoir Eco-environment,

Chongqing University, Chongqing 400045, People's Republic of China

\section{Background}

With the increase in requirement of food and natural resources from rural regions to sustain burgeoning number of urban residents, rural environments are seriously

\section{Springer Open}

(c) The Author(s) 2021. This article is licensed under a Creative Commons Attribution 4.0 International License, which permits use, sharing, adaptation, distribution and reproduction in any medium or format, as long as you give appropriate credit to the original author(s) and the source, provide a link to the Creative Commons licence, and indicate if changes were made. The images or other third party material in this article are included in the article's Creative Commons licence, unless indicated otherwise in a credit line to the material. If material is not included in the article's Creative Commons licence and your intended use is not permitted by statutory regulation or exceeds the permitted use, you will need to obtain permission directly from the copyright holder. To view a copy of this licence, visit http://creativeco mmons.org/licenses/by/4.0/. 
polluted by contaminants from agriculture, breeding, industrial, tourism and so on. It is reported that in China, the total emission of chemical oxygen demand (COD), nitrogen and phosphorus from agriculture account for $43.7 \%, 57.2 \%$ and $67.3 \%$ of the total national emissions, respectively [1]. In 2010, the COD and ammonia nitrogen discharged by the livestock and poultry breeding accounted for $45 \%$ and $25 \%$ of the nationwide emissions in China [2]. Thus, rural environment management, as one of the most important components of rural development, has aroused wide concern in recent years [3].

United States Department of Agriculture [4] office released a series of programs, such as Rural Decentralized Water Systems Grant Program, Solid Waste Management Grants, Water \& Waste Disposal Grants to Alleviate Health Risks on Tribal Lands and Colonias, SEARCH-Special Evaluation Assistance for Rural Communities and Households, Water \& Waste Disposal Technical Assistance \& Training Grants and so on to protect water and environment in rural areas [4]. In China, the project of "green livable village program" was launched in 2018 by the Ministry of Science and Technology of the People's Republic of China (MOST) to improve the rural living environment and to promote the coordination of agricultural production, living condition and ecological conservation [3]. However, studies on the harmful effects of objective water quality and measures aimed at controlling environmental pollution have been taken mainly in cities, since the rural residents' weak awareness of environmental protection and less judgement on the harm of environmental pollution [1]. The monitoring of water quality is always time-consuming, and a cumbersome task requiring manual laboratory analysis and statistical inferences, since there is no single parameter that defines environment quality completely [5]. The laboratory facilities and test are normally quite limited in rural areas. In addition, most of the water supply and drainage are decentralized and differed distinctly with type of villages. For instance, in farming villages, pesticides and fertilizers are main pollutants; in breeding villages, livestock is the major pollution source; in industrial villages, the dominant pollutants are often related to the corresponding industrial production; and in mixed villages which involve agriculture, breeding, industry, the environmental pollutants are usually mixture of different kinds of chemicals. These different types of villages and pollutants increased the difficulty of water quality monitoring in rural areas. Thus, most of rural surface water quality monitoring programs just focus on the comprehensive conventional parameters, such as $\mathrm{pH}$, dissolved oxygen [6], electrical conductivity (EC) and oxidation reduction potential (ORP) which are easily and quickly tested in situ, and chemical oxygen demand (COD), total nitrogen (TN), and total phosphorus (TP) which require less laboratory facilities during parameter detection. While can these conventional parameters reflect comprehensive status of water quality and direct water quality management in rural areas?

The ultimate objective of water quality monitoring, evaluation, management is to ensure the safety of water environment. Bioanalytical techniques of effect-based bioassays which account for the toxic effects of complex environmental mixtures could evaluate the safety of tested samples directly [7]. To study how much the conventional parameters contribute to biological toxicity of surface water in villages, surface water samples were collected from six types of Chinese villages, named breeding, agricultural, handicraft, industrial, agricultural and breeding, and tourism. In situ parameters of $\mathrm{pH}, \mathrm{DO}, \mathrm{EC}, \mathrm{ORP}$ and laboratorial parameters of COD, $\mathrm{TN}, \mathrm{NO}_{3}{ }^{-}-\mathrm{N}, \mathrm{NO}_{2}{ }^{-}-\mathrm{N}, \mathrm{NH}_{4}{ }^{+}-\mathrm{N}, \mathrm{TP}$, and $\mathrm{PO}_{4}{ }^{3-}$-P were detected for the collected samples. The luminescent bacteria 502 which were reported to be an ideal model for acute toxicity evaluation, and closely resemble the enzyme activity levels of the current population [6] were applied to indicate the safety of water samples in the current study. Finally, correlations between acute toxicity and water conventional parameters were analyzed to establish the linkages and contributions of each parameter during water quality monitoring.

\section{Methods \\ Study area}

In the current study, 13 study villages located in four provinces (Liaoning, Qinghai, Sichuan and Shanghai) with representative different geographic characteristics in China. The frequent underground/surface water interaction (U/S interaction), alternation of drying and wetting (D/W alternation), and freezing-thawing transition ( $\mathrm{F} / \mathrm{T}$ transition) are typical rural natural environmental processes in river network regions, mountainous regions and cold regions of China, respectively. These biogeochemical processes play important roles for pollutants transportation, transformation, and source-to-sink patterns of pollutants, which may result in variations of hazards in rural environments [3]. In each province, 3-4 villages of different types were selected for surface water sample collection (Fig. 1 and Additional file 1: Table S1). Each village is of medium size locally, no wastewater management systems have been built with the exception for the villages in Shanghai. The backbone industry of study villages includes agricultural, industrial, breeding, handicraft and tourism. 


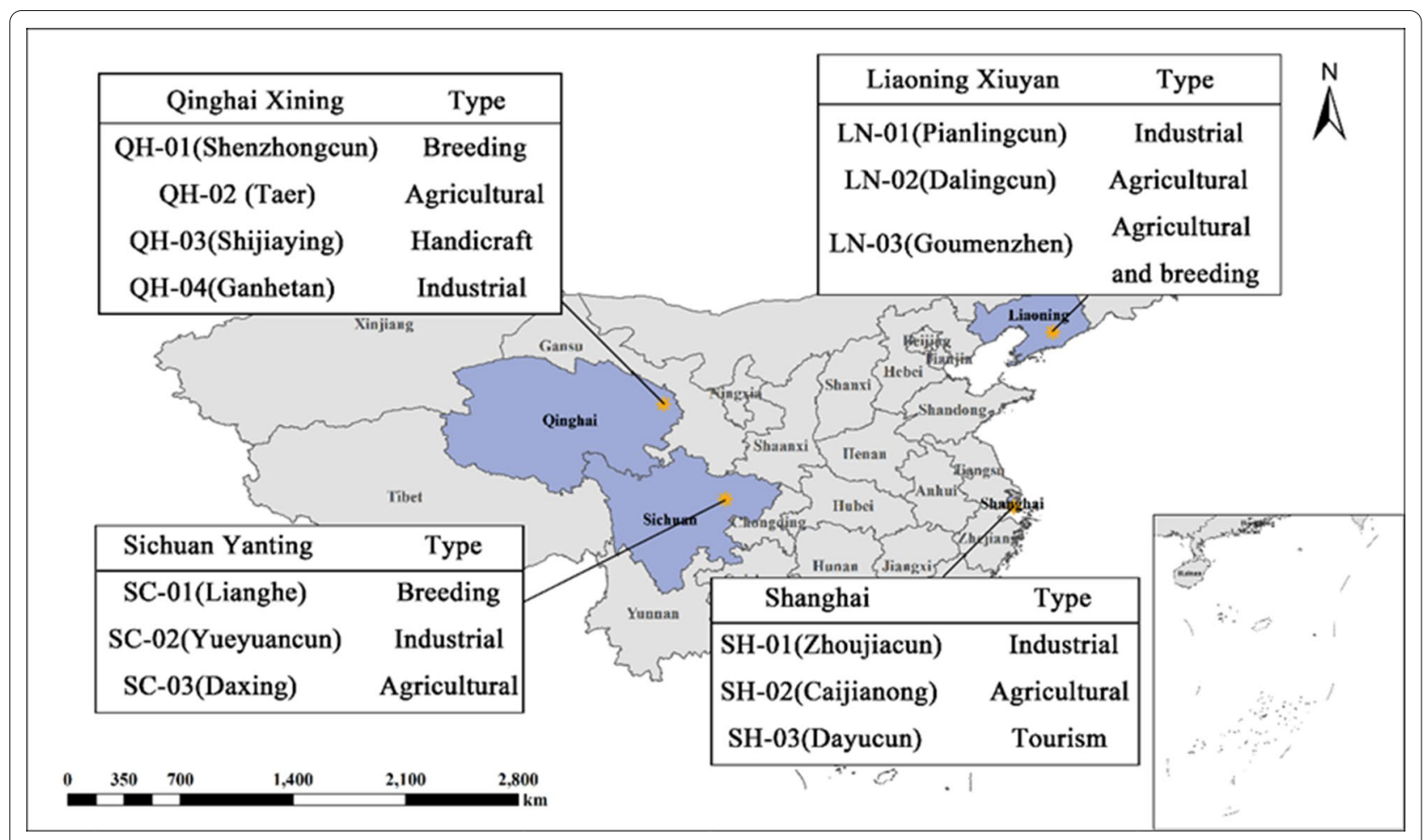

Fig. 1 Location of the study area

\section{In situ parameter determination}

The parameters of $\mathrm{pH}$, dissolved oxygen (DO), oxidation-reduction potential (ORP) and electrical conductivity (EC) were measured in the field by a multiparameter water quality monitoring instrument (YSI Professional Plus, USA) [8].

\section{Sample collection and storage}

Sample collection in this study was conducted between July and September 2020. At least three sampling sites were set up in each village. A total of $1000 \mathrm{~mL}$ water sample was collected from each sampling site, among which $500 \mathrm{~mL}$ sample was collected and stored in a plastic bottle at $-20{ }^{\circ} \mathrm{C}$ for conventional parameters detection, and the other $500 \mathrm{~mL}$ sample were filtrated via $0.45 \mu \mathrm{m}$ PES syringe filter (Jinteng, Tianjin, China) and stored in a glass bottle at $-20^{\circ} \mathrm{C}$ for toxicity evaluation.

\section{Laboratorial parameters analysis}

The total nitrogen (TN) was detected by ultraviolet spectrophotometry with basic potassium persulfate [9]. Firstly, $10 \mathrm{~mL}$ sample was added with $5 \mathrm{~mL}$ basic potassium persulfate, and was then digested at $121{ }^{\circ} \mathrm{C}$ for $30 \mathrm{~min}$. After cooling, $1 \mathrm{~mL}$ hydrochloric acid ( $\mathrm{HCl}$ :deionized water; $\mathrm{v}: \mathrm{v}=1: 9)$ was added into the solution, following by filling up the solution to $25 \mathrm{~mL}$ by deionized water. The analysis was done by measuring the absorbance of the treated sample at $220 \mathrm{~nm}$ and $275 \mathrm{~nm}$, and the values was obtained by calculation $\left(A=A_{220}\right.$ $\left.-2 \mathrm{~A}_{275}\right)$.

The nitrate $\left(\mathrm{NO}_{3}{ }^{-}-\mathrm{N}\right)$ was measured via sulfamic acid spectrophotometric method [10]. Firstly, $5 \mathrm{~mL}$ water sample was added to a volumetric flask and fixed up to $50 \mathrm{~mL}$ with deionized water, followed by added with $1 \mathrm{~mL}$ hydrochloric acid $(1 \mathrm{~mol} / \mathrm{L})$. After sufficiently shaking, $0.1 \mathrm{~mL}$ sulfamic acid was added into the flask. The absorbances at $220 \mathrm{~nm}$ and $275 \mathrm{~nm}$ were measured by spectrophotometer with the sample in a quartz cuvette, and the two absorbance values were subtracted to obtain $\mathrm{A}\left(\mathrm{A}=\mathrm{A}_{220}-2 \mathrm{~A}_{275}\right)$.

$N$-(1-naphthyl)-2 Ethylenediamine photometric method was used to determine the concentration of nitrite $\left(\mathrm{NO}_{2}{ }^{-}-\mathrm{N}\right)$ in water samples [10]. Briefly, $1 \mathrm{~mL}$ of water sample was placed in a $50 \mathrm{~mL}$ colorimetric tube and diluted with deionized water up to $50 \mathrm{~mL}$. Afterwards, $1.0 \mathrm{~mL}$ of chromogenic agent containing $0.17 \mathrm{~g} /$ $\mathrm{mL}$ phosphoric acid, $40 \mathrm{~g} / \mathrm{mL}$ p-aminobenzenesulfonamide and $2 \mathrm{~g} / \mathrm{mL} \mathrm{N}$-(1-naphthyl)-ethylenediamine dihydrochloride was added to the solution. The solution was sufficiently mixed and left to stand for $20 \mathrm{~min}$. Using deionized water as reference, the absorbance at $540 \mathrm{~nm}$ was measured with a cuvette of $10 \mathrm{~nm}$ optical path. 
The concentration of ammonium $\left(\mathrm{NH}_{4}{ }^{+}-\mathrm{N}\right)$ was obtained by salicylic acid-hypochlorite spectrophotometric method $[6,11]$. Briefly, $5 \mathrm{~mL}$ water sample was transferred into a $10 \mathrm{~mL}$ colorimetric tube, diluted to $8 \mathrm{~mL}$ with deionized water. And then, $1.00 \mathrm{~mL}$ chromogenic agent $(50 \mathrm{~g} / \mathrm{L}$ salicylic acid, $50 \mathrm{~g} / \mathrm{L}$ potassium sodium tartrate and $1.28 \mathrm{~g} / \mathrm{L}$ sodium hydroxide) and 2 drops of sodium nitrosoferricyanide solution $(0.1 \mathrm{~g} / \mathrm{mL})$ were added into the tube. After sufficiently mixed, 2 drops of sodium hypochlorite solution were added into the solution, and finally the solution was diluted up to $10 \mathrm{~mL}$. After standing for $1 \mathrm{~h}$, the absorbance was measured at $697 \mathrm{~nm}$ using a cuvette of $10 \mathrm{~nm}$ optical path [11].

The total phosphorus (TP) was analyzed by ammonium molybdate spectrophotometric method with potassium persulfate as the digestion oxidant [8]. Briefly, $25 \mathrm{~mL}$ water sample was added into a 50-mL colorimetric tube, and then $4 \mathrm{~mL}$ of potassium persulfate was added. After digestion at $121{ }^{\circ} \mathrm{C}$ for $30 \mathrm{~min}, 1 \mathrm{~mL}$ of $10 \%$ ascorbic acid was added and mixed intensively, followed by adding $2 \mathrm{~mL}$ of molybdate solution. After sufficiently mixing and then standing for $15 \mathrm{~min}$, the sample was placed in a $10-\mathrm{mm}$ cuvette and the absorbance was measured at $700 \mathrm{~nm}$.

To determine the concentration of phosphate $\left(\mathrm{PO}_{4}{ }^{3-}-\mathrm{P}\right), 10 \mathrm{~mL}$ of the sample was placed in a $50-\mathrm{mL}$ colorimetric tube, in which $2 \mathrm{~mL}$ of ammonium molybdate solution and $3.0 \mathrm{~mL}$ of ascorbic acid solution were added as chromogenic agent, and the solution was diluted up to $50 \mathrm{~mL}$ with deionized water. After sufficiently mixing and standing for $10 \mathrm{~min}$ at room temperature, the absorbance of sample was measured at $710 \mathrm{~nm}$ using a cuvette with an optical range of $1 \mathrm{~cm}$ and zeroed with a blank without the tested solution [8].

The chemical oxygen demand (COD) was determined by a colorimetric dosing method using a spectrophotometer. Firstly, $1 \mathrm{~mL}$ mercury sulfate was added into the dry cuvette to shield the $\mathrm{Cl}^{-}$. Then $2.25 \mathrm{~mL}$ of solution A (concentrated sulfuric acid containing silver sulfate, where the concentration of sulfuric acid is $98 \%$, and the ratio of silver sulfate to concentrated sulfuric acid is $10 \mathrm{~g}: 1 \mathrm{~L}$ ), $0.75 \mathrm{~mL}$ of solution $\mathrm{B}$ (potassium dichromate solution with a concentration of $0.167 \mathrm{~mol} / \mathrm{L}$ ) and $2 \mathrm{~mL}$ of water sample were added to the cuvette in turn, and the bottle was tightly capped and shaken sufficiently. The COD concentration was determined after digestion at $150{ }^{\circ} \mathrm{C}$ for $2 \mathrm{~h}$, and then cooled to room temperature. The total organic carbon (TOC) concentration was measured using a TOC analyzer (Shimadzu TOC-L, Japan) [12]. Each sample was subjected to at least three parallel independent experiments. Except for TOC, the value of each physicochemical parameter was determined by finding the concentration value corresponding to the absorbance on a standard curve, which was plotted using a standard solution with a known concentration gradient. The ranges of detection are $0.05-4 \mathrm{mg} / \mathrm{L}, 0.08-4 \mathrm{mg} / \mathrm{L}$, $0.003-0.2 \mathrm{mg} / \mathrm{L}, 0.01-1 \mathrm{mg} / \mathrm{L}, 0.01-0.6 \mathrm{mg} / \mathrm{L}$ and $0.05-$ $1000 \mathrm{mg} / \mathrm{L}$ for TN, $\mathrm{NO}_{3}{ }^{-}-\mathrm{N}, \mathrm{NO}_{2}{ }^{-}-\mathrm{N}, \mathrm{NH}_{4}{ }^{+}-\mathrm{N}, \mathrm{TP}$ and COD, respectively.

\section{Toxicity evaluation}

For the toxicity evaluation, luminescent bacteria 502 was utilized. The lyophilized powder of luminescent bacteria was taken out from the $-80{ }^{\circ} \mathrm{C}$ and placed at $20{ }^{\circ} \mathrm{C}$ for $10 \mathrm{~min}$. Then, the recovery medium was added for rehydration at $20{ }^{\circ} \mathrm{C}$ for $15 \mathrm{~min}$. The luminescent bacteria acute toxicity assay protocol was based on the method described by Chen et al.[6]. Toxicity of surface water samples were evaluated by measuring the inhibition of bioluminescence of luminescent bacterial strains. The luminescence inhibition assay was performed in test tubes using a luminometer (BHP9514, Beijing Hamamatsu Photon Techniques INC.). For each test, 10 test tubes were prepared, eight for different water samples, one for negative control (recovery liquid) and one for positive control $\left(\mathrm{ZnSO}_{4} \cdot 7 \mathrm{H}_{2} \mathrm{O}\right.$ at $\left.5 \mathrm{mg} / \mathrm{L}\right)$. Sample or control liquid $(1 \mathrm{~mL})$ was added after pretreated with osmotic pressure regulator, and the bacterial suspension $(50 \mu \mathrm{L})$ was added with $10 \mathrm{~s}$ intervals. After $15 \mathrm{~min}$ exposure of the bacteria to the sample at $20{ }^{\circ} \mathrm{C}$, the relative light unit (LU) of luminescent bacterium 502 was measured. The acute toxicity of the sample on strain 502 was expressed as an inhibition ratio, calculated by the following formulation [6]:

$$
\mathrm{X} \%=\left(1-\mathrm{LU} / \mathrm{LU}_{0}\right) \times 100
$$

where $\mathrm{LU}_{0}$ was the RLU of strain 502 exposed to the negative control and LU was the RLU of the samples. Each test was carried out with three independent replicates.

\section{Statistical analysis}

Spatial visualization of all data was analyzed based on ArcGIS 10.4.1 (ESRI, USA). All the experimental data were analyzed by Microsoft Excel ${ }^{\mathrm{TM}} 2016$ and Origin 2019 (Origin Lab Corporation). One-way analysis of variance (ANOVA) was applied for statistically significant differences testing. The correlation analysis was run based on the $\mathrm{R}$ programming language ( $\mathrm{R}$ Development Core Team 2018). Pearson's correlation analysis was applied to reveal the correlation between the acute toxicity of luminescent bacteria 502 and each conventional parameter [6]. Two significance levels of $p<0.05$ and $p<0.01$ were used to define statistical significance. 


\section{Results and discussion}

In situ parameters of aquatic environment

The results of in situ detected parameters are shown in Fig. 2. The concentrations of DO in rural surface water ranged from $1.40 \mathrm{mg} / \mathrm{L}$ to $15.50 \mathrm{mg} / \mathrm{L}$, with the mean value of $8.58 \mathrm{mg} / \mathrm{L}$ (Fig. 2A). The highest DO concentration was obtained in an agriculture village in Sichuan, and the lowest one was found in a tourist village (SH03) in Shanghai. The diverse DO concentrations could be related to the different hydrological features as well as varied aquatic vegetation patterns in villages [13]. Besides, the ORP values in Shanghai were slightly less than that in other study sites (Fig. 2B), which may indicate that reductive substances are in the majority in Shanghai surface water [14]. We found that the EC value in rural surface water amounted from $0.118 \mathrm{mS} /$ $\mathrm{cm}$ to $1.47 \mathrm{mS} / \mathrm{cm}$ (Fig. 2C). The highest EC appeared in the industrial village in Xining (Qinghai) where is surrounded with metallurgical industry and mineral industry. All the observed $\mathrm{pH}$ values were between 7 and 9, which means that surface water in China rural areas is weak alkaline (Fig. 2D). The $\mathrm{pH}$ of the water sample has little effect on acute toxicity [15].

\section{Laboratorial parameters of aquatic environment}

As can be seen from Fig. 3, the $\mathrm{TN}, \mathrm{NO}_{3}{ }^{-}-\mathrm{N}, \mathrm{NO}_{2}{ }^{-}-\mathrm{N}$ and $\mathrm{NH}_{4}{ }^{+}-\mathrm{N}$ concentrations of all 13 sites ranged from
$2.37 \mathrm{mg} / \mathrm{L}$ to $11.31 \mathrm{mg} / \mathrm{L}, 0.93 \mathrm{mg} / \mathrm{L}$ to $6.96 \mathrm{mg} / \mathrm{L}$, $0.20 \mathrm{mg} / \mathrm{L}$ to $0.04 \mathrm{mg} / \mathrm{L}$, and $0.07 \mathrm{mg} / \mathrm{L}$ to $1.11 \mathrm{mg} / \mathrm{L}$, respectively. It is noticed that the concentrations of $\mathrm{TN}$ in all studied areas were beyond the limits $(2.0 \mathrm{mg} / \mathrm{L})$ for Class V water that specified by GB3838-2002 (environmental quality standard for surface water, Additional file 1: Table S2) [16], indicating that all of these studied surface water cannot be used for agriculture, industry, landscape and entertainment [16]. The concentration of $\mathrm{TN}, \mathrm{NO}_{3}{ }^{-}-\mathrm{N}$ and $\mathrm{NO}_{2}{ }^{-}-\mathrm{N}$ in the site $\mathrm{HQ}-04$ which located in an industrial village in Ganhetan, north of Lushaer, Huanzhong County, Qinghai Province, was significantly higher than that in other sites. The industrial village takes smelting, building materials and in particular chemical industry as the main industries, which could be a reason for nitrogen pollution in this area. The lowest mean value of $\mathrm{TN}$ and $\mathrm{NO}_{3}{ }^{-}-\mathrm{N}$ concentration was found in the tourist village ( $\mathrm{SH}-03)$, which indicates that the tourism may contribute less to nitrogen pollution in rural areas when compared to agriculture, breeding, handicraft and industry. Besides, the highest $\mathrm{NH}_{4}{ }^{+}-\mathrm{N}$ concentration was found in the site $\mathrm{SH}-02$ which located in an agricultural village in Shanghai. The possible reason could be that the main agricultures in Caijianong village is vegetable cultivation, such as cabbage, papaya and lotus root. The rapid growth of these vegetables requires a lot of nitrogen fertilizers, and more than $95 \%$ of synthetic
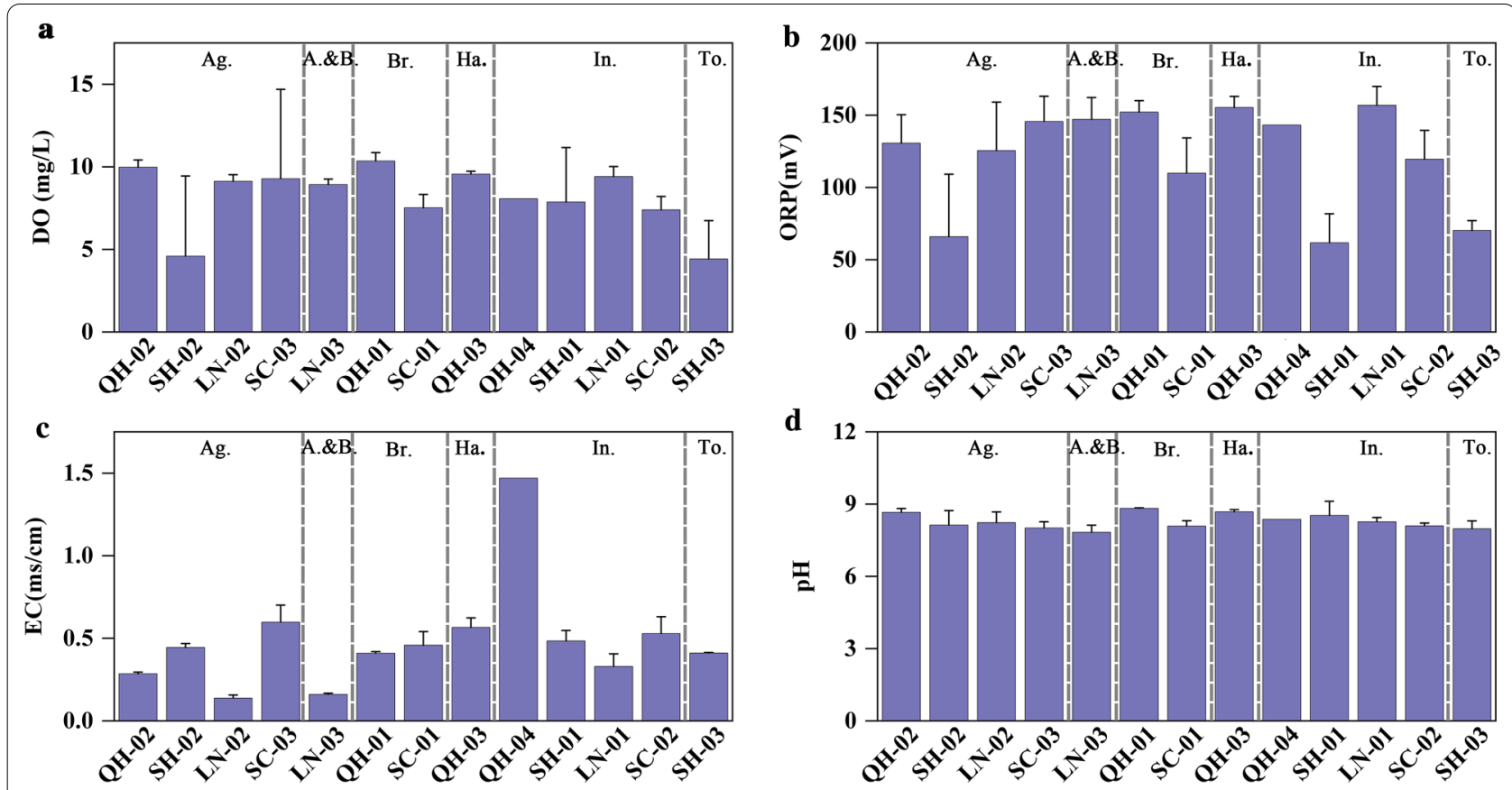

d

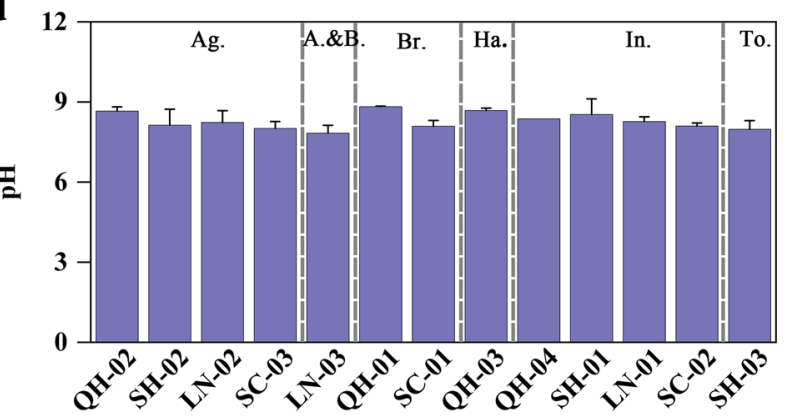

Fig. $\mathbf{2}$ In situ parameters of $\mathbf{A}$ dissolved oxygen (DO) concentration, B oxidation-reduction potential (ORP) value, $\mathbf{C}$ electrical conductivity (EC) value and $\mathbf{D}$ pH value in different types of village surface water. Ag.: agricultural village; A.\&B.: agriculture and breeding mixed village; Br.: breeding village; Ha.: handicraft village; In.: industrial village; To.: tourism village 

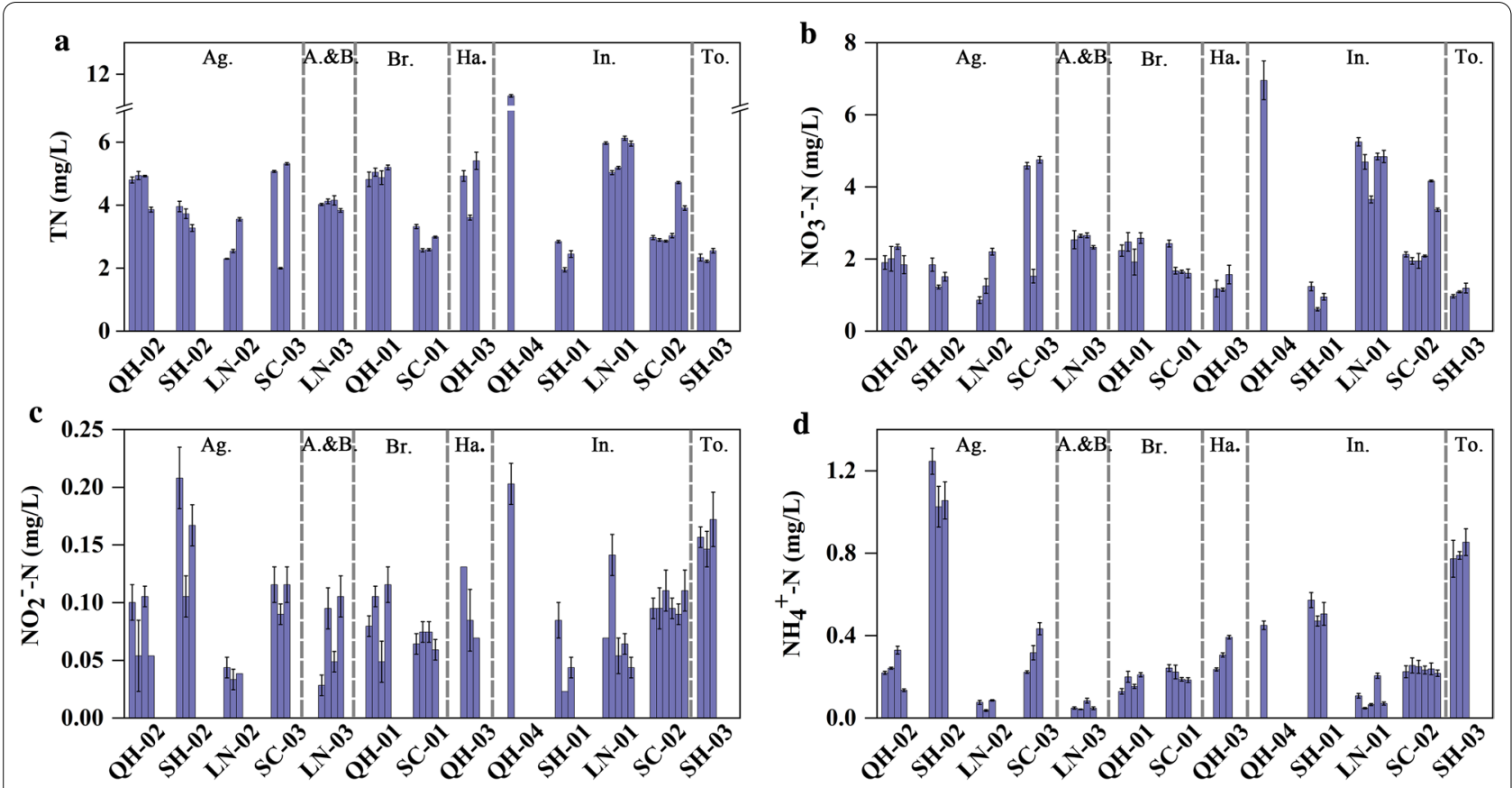

Fig. 3 The concentration of $\mathbf{A}$ total phosphorus (TP), $\mathbf{B ~ N O}{ }_{3}^{-}-\mathrm{N}, \mathbf{C ~ N O}_{2}{ }^{-}-\mathrm{N}$ and $\mathbf{D} \mathrm{NH}_{4}{ }^{+}-\mathrm{N}$ in different types of village surface water. Ag.: agricultural village; A.\&B.: agriculture and breeding mixed village; Br.: breeding village; Ha.: handicraft village; In.: industrial village; To.: tourism village

nitrogen fertilizers are urea and ammonium nitrogen [17]. Concerning the proportions of $\mathrm{NH}_{4}{ }^{+}-\mathrm{N}$ in $\mathrm{TN}$, agricultural villages are significantly higher than industrial villages, which give an further evidence for that ammoniated fertilizer is one of most important sources of nitrogen pollution in agricultural villages [18].

Figure 4 shows the detected concentrations of TP, $\mathrm{PO}_{4}{ }^{3-}-\mathrm{P}, \mathrm{COD}$ and TOC in 13 sampling sites. The lowest $\mathrm{TP}$ and $\mathrm{PO}_{4}{ }^{3-}$-P were observed in an industrial village (SC-02) with the concentration of $0.071 \mathrm{mg} / \mathrm{L}$ and $0.049 \mathrm{mg} / \mathrm{L}$, respectively (Fig. 4A, B). The industry of this village is mainly for construction materials and auto parts. These results indicate that the industry of construction materials and auto parts could be less contributing to phosphorus pollution [19]. Interestingly, the lowest TOC concentration was detected in a breeding village (SC-01) with swine as the main farmed specie. The concentrations of COD ranged from $26.58 \mathrm{mg} / \mathrm{L}$ to $119 \mathrm{mg} / \mathrm{L}$ in 13 sampling sites (Fig. 4C). Most of these COD concentrations exceeded the Class V limits $(40.0 \mathrm{mg} / \mathrm{L})$ that specified by GB3838-2002, and thus the waters cannot be used for agriculture, industry, landscape and entertainment [16]. Significantly, the highest concentrations of TP, $\mathrm{PO}_{4}{ }^{3-}-\mathrm{P}, \mathrm{COD}$ and TOC were found in the site QH-04 (Fig. 4D) which exhibited the highest concentrations of $\mathrm{TN}, \mathrm{NO}_{3}{ }^{-}-\mathrm{N}$ and $\mathrm{NO}_{2}{ }^{-}-\mathrm{N}$. These results demonstrated that smelting, building materials and chemical industry could be a vital source of carbon, nitrogen and phosphorus pollution [20], which should be of concern during environment management and development in rural areas.

\section{Toxicity of aquatic environment}

To evaluate the toxicity of surface water samples from different types of villages, the luminescent bacteria acute toxicity test was applied in the current study. Six out of 48 samples induced significantly toxicity on luminescent bacteria 502, as shown in Fig. 5. The highest inhibition rate of luminescence intensity was observed in the $\mathrm{SH}-02$ of Caijianong which is located at an agricultural village in Shanghai. This result indicates that pollution from agriculture could be one of important environmental risk sources, of which the relative high concentrations have been found in the surface water in these areas [21]. A large number of pesticides such as insecticides, herbicides and fungicides are used in the process of cultivating crops. Organochlorine pesticides (OCPs) are one of the most widely used pesticides [22]. They interfere with the membrane transport system of sodium, potassium, calcium or chloride ions, thereby inhibiting the selective enzymatic activity of chemical transmission at nerve endings [23]. Herbicides can affect photosynthesis, respiration, growth, cell and nuclear division, or protein or lipid synthesis processes [24]. Fungicides interfere with fungal energy supply processes and inhibit spore germination $[25,26]$. Except for agricultural pollution, pollutants from 

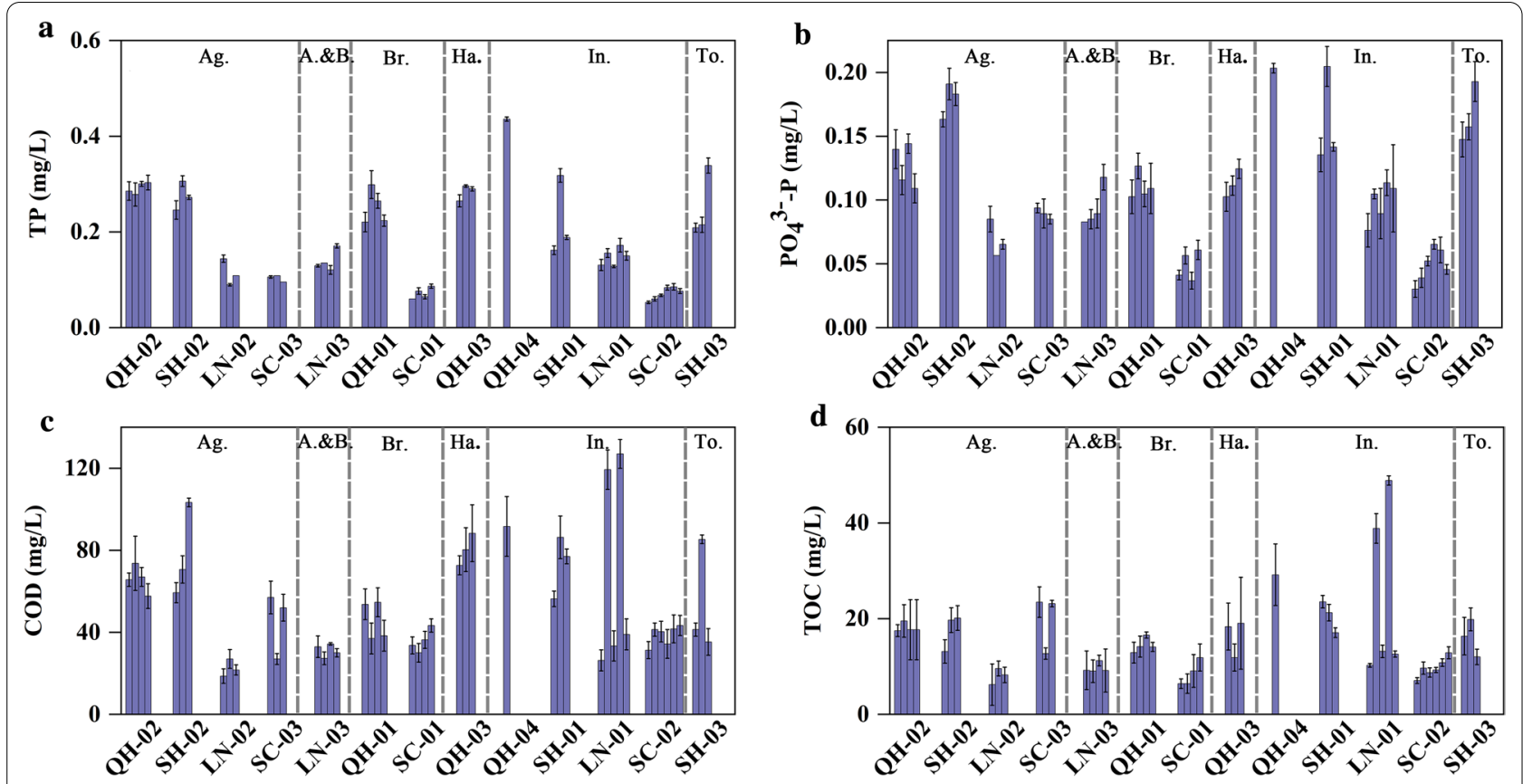

Fig. 4 The concentration of $\mathbf{A}$ total nitrogen (TP), $\mathbf{B} \mathrm{PO}_{4}{ }^{3-}-\mathrm{P}, \mathbf{C}$ chemical oxygen demand (COD) and $\mathbf{D}$ total organic carbon (TOC) in different types of village surface water. Ag.: agricultural village; A.\&B.: agriculture and breeding mixed village; Br.: breeding village; Ha.: handicraft village; In.: industrial village; To.: tourism village

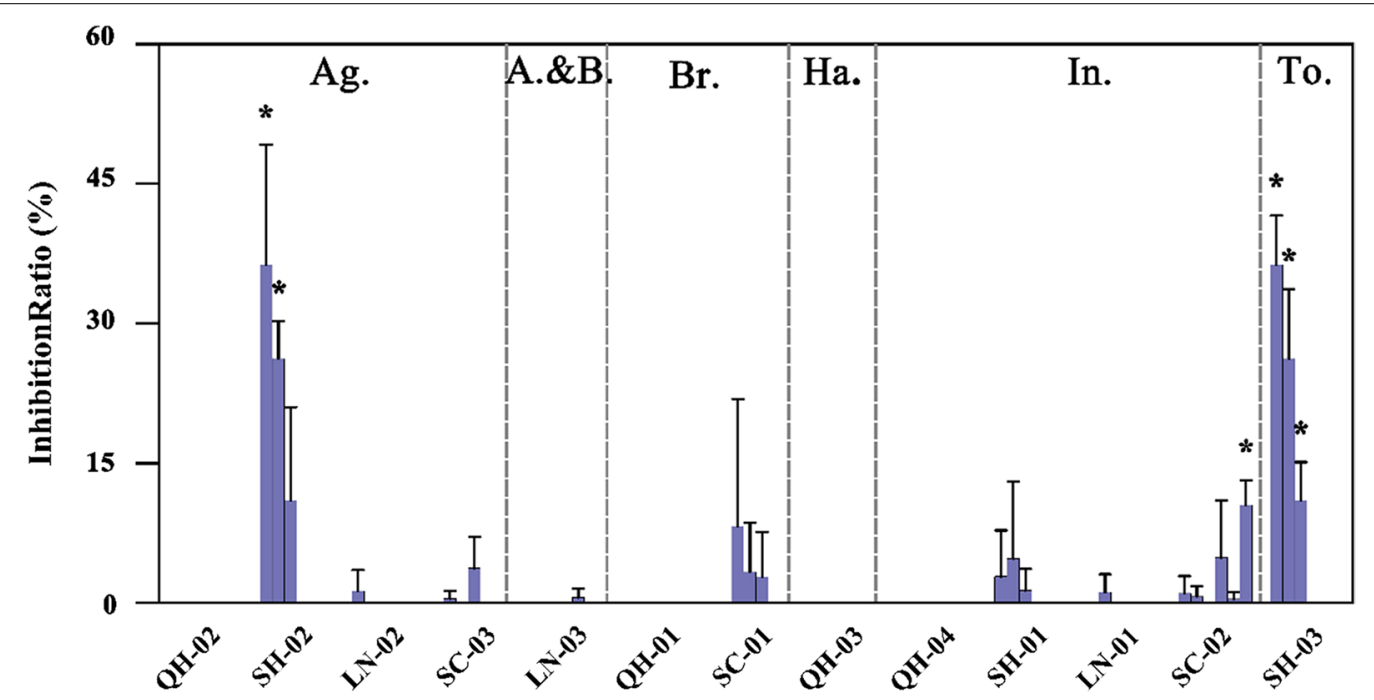

Fig. 5 Luminescent bacterial acute toxicity of surface water in different types of villages. Ag.: agricultural village; A.\&B.: agriculture and breeding mixed village; Br.: breeding village; Ha.: handicraft village; In.: industrial village; To.: tourism village

tourism should not be ignored, since significant luminescence inhibition was observed in all tourism water samples. With the rapid development of tourism industry, more and more urban residents would like to travel to rural villages. Accordingly, lots of domestic wastewater and household waste were released irregularly, since very limited drainage system and refuse collector are available in rural villages. These may lead to serious problems for rural environments. For instance, the West Lake in Hangzhou, as one of the most famous tourist city in China, carried a large number of visitors and an increasing loads of garbage and domestic sewage. According to 
the Tourism Bureau, the comprehensive pollution index of West Lake from 2007 to 2018 is on an upward trend, and the ecological environment has been significantly affected [27]. In addition, a survey of Santa Marta Beach in the Colombian Caribbean found a significant increase in the amount of litter and microplastics during the peak tourist season [28].Tourism in Cyprus (North) also increases the amount of local pollutant emissions, which leads to environmental degradation [29].

\section{Correlation analysis}

The correlation between acute toxicity and each conventional parameter was analyzed by Pearson correlation test for the 48 surface water samples from different kinds of villages. Significant linkages between acute toxicity effects and conventional parameters were obtained (Fig. 6).

In agricultural villages, the acute toxicity effects of surface water were significantly positive correlated with laboratory parameters including $\mathrm{NO}_{2}-\mathrm{N}^{-}(r=0.72, p<0.05)$, $\mathrm{NH}_{4}{ }^{+}-\mathrm{N} \quad(r=0.90, \quad p<0.05)$ and $\mathrm{PO}_{4}{ }^{3-}-\mathrm{P} \quad(r=0.68$, $p<0.05$ ) (Fig. 6A). These results suggest that the acute toxicity of surface water from agricultural villages may be induced by inorganic nitrogen and phosphorus pollutants [30]. In particular, the correlation coefficient for $\mathrm{NH}_{4}{ }^{+}-\mathrm{N}$ and acute toxicity was 0.90 . This result provided a further

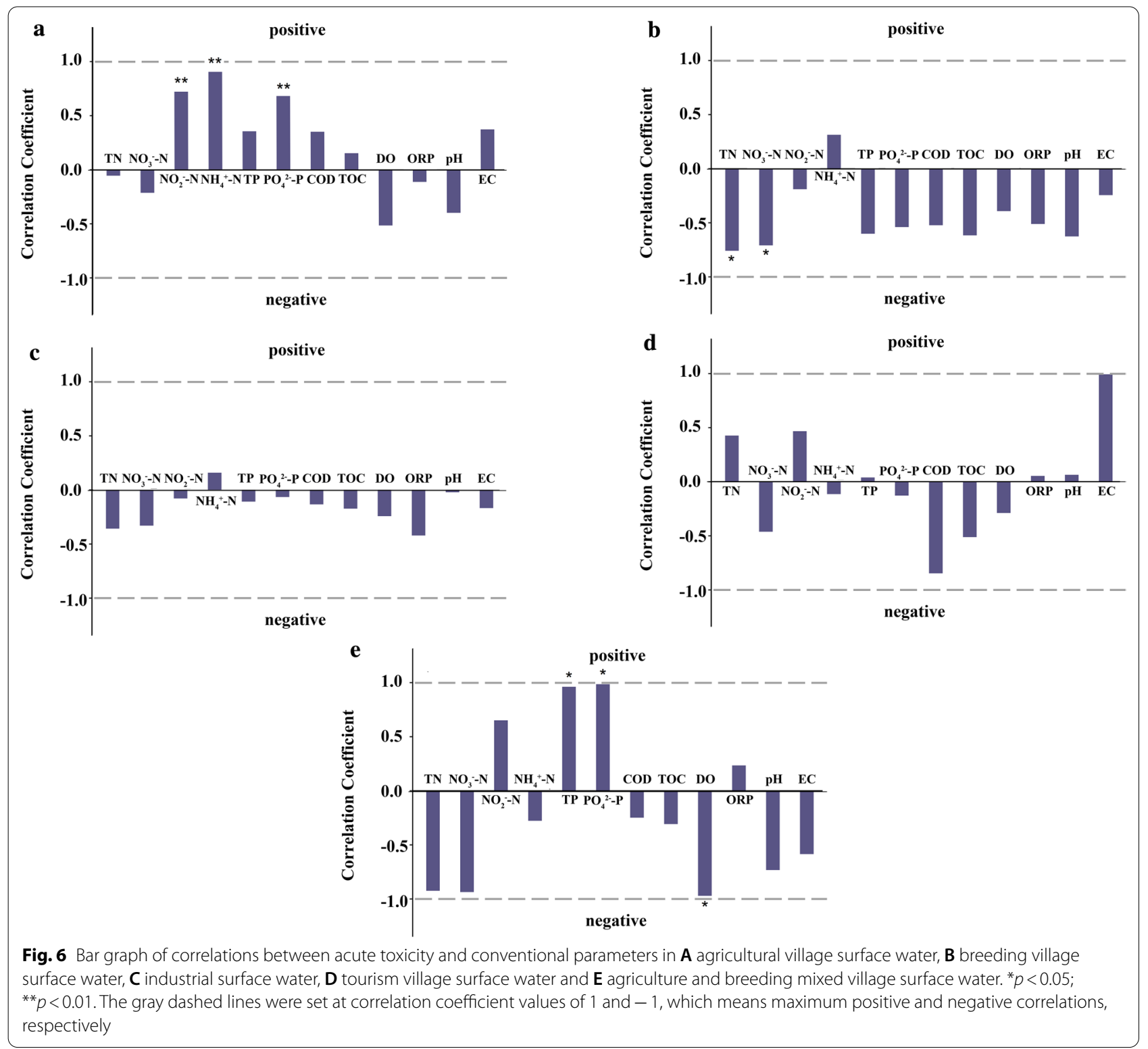


evidence that ammoniated fertilizer is a hazardous material, which has to be taken seriously. In breeding villages, except for $\mathrm{NH}_{4}{ }^{+}-\mathrm{N}$, the current observed conventional parameters were negatively correlated with the toxicity of surface water (Fig. 6B). These observations indicate that the acute toxicity of surface water in the breeding villages may not be caused by the conventional parameters. It is reported that besides carbon, nitrogen and phosphorus, heavy metals and antibiotics which can induce toxic effects on aquatic organisms/microorganisms were also frequently detected in breeding villages [9]. For instance, quinolones, one of widely used antibiotics in livestock breeding, can inhibit protein synthesis and interfere with DNA replication; erythromycin can restrain photosynthesis-related processes, such as electron transport, photosynthetic phosphorylation and carbon assimilation [31]; tetracyclines may be related to the inhibition of chloroplast metabolism-related pathways, which ultimately affect cell growth by interfering with the function of photosynthetic organs [32]. Cu causes a decrease in $\mathrm{Na}^{+}$concentration in fish gill tissue, and affects the expression of oxidative stress-related genes such as catalase, glutathione reductase and glutathione S-transferase [33]. Zinc can affect the development, sexual maturation and reproduction of aquatic organisms by disrupting thyroid hormones [34]. Similar results were also found in industrial villages (Fig. 6C), which suggested that in breeding and industrial villages, the toxicity of surface water may not cause by the carbon, nitrogen and phosphorus pollution. The main toxic contributors are quite difference in diverse industrial fields. In electronic industry, the main toxic contributors could be heavy metals [35]. While in the village with dyeing industry as a pillar industry, the organic dyes may contribute to the toxicity of surface water [36]. In tourism villages, except for TN, $\mathrm{NO}_{2}{ }^{-}-\mathrm{N}, \mathrm{TP}$ and EC, other conventional parameters are negative correlated with the acute toxic effects, while no significant correlation was observed. In mixed villages which agriculture and breeding are mainstay industry, the acute toxicity was significantly correlated with the TP and $\mathrm{PO}_{4}{ }^{3-}-\mathrm{P}$ with the coefficient of 0.96 and 0.99 , respectively. The possible reason could be that both agricultural production and livestock breeding can produce lots of phosphorus pollutants [37]. It is noticed that positive correlation was obtained for $\mathrm{NH}_{4}{ }^{+}-\mathrm{N}$ and acute toxicity in agriculture villages, breeding villages and industrial villages, which further proved that $\mathrm{NH}_{4}{ }^{+}-\mathrm{N}$ is a serious problem in rural areas.

\section{Conclusions}

The surface water involved in the hydrological cycle is the basis for many human uses. In rural areas, pollutants induced great variation in surface water quality may lead to serious problems for aquatic ecosystem and even human health. Our study found that $\mathrm{NH}_{4}{ }^{+}-\mathrm{N}$ could contribute to the acute toxicity in most of villages, and the harmful influence of ammoniated fertilizer should be taken seriously. In agricultural villages, classical water quality parameters of $\mathrm{NO}_{2}{ }^{-} \mathrm{N}, \mathrm{NH}_{4}{ }^{+}-\mathrm{N}$ and $\mathrm{PO}_{4}{ }^{3-}-\mathrm{P}$ could contribute to the toxicity of surface water, while no significant correlation was observed between acute toxicity and conventional parameters in industrial villages and tourism villages. These results indicate that environmental monitoring programs focus just on the classical conventional parameters is far from enough, since the main toxic contributors are quite different in diverse villages. More toxic parameters could be added and seasonal variations should be taken into consideration in further monitoring programs during environmental management to assess the safety of water quality directly. The outcomes of the present study contribute to demonstrate the performance and usefulness of bioanalytical techniques for water quality assessment. These efforts provide the scientific underpinnings and regulatory reference for derivation of environmental quality standards. These works, combined with long-term monitoring data, could provide scientific underpinnings and regulatory reference for derivation of environmental quality standards, and thus contribute to environmental management in rural areas around the world.

\section{Abbreviations}

COD: Chemical oxygen demand; USDA: United States Department of Agriculture; MOST: Ministry of Science and Technology of the People's Republic of China; DO: Dissolved oxygen; EC: Electrical conductivity; ORP: Oxidation reduction potential; TN: Total nitrogen; TP: Total phosphorus; $\mathrm{NO}_{3}{ }^{-}{ }^{-} \mathrm{N}$ : Nitrate; $\mathrm{NO}_{2}{ }^{-}-\mathrm{N}$ : Nitrite; $\mathrm{PO}_{4}{ }^{3-}-\mathrm{P}$ : Phosphate; TOC: Total organic carbon; LU: Light unit; RLU: Relative light unit.

\section{Supplementary Information}

The online version contains supplementary material available at https://doi. org/10.1186/s12302-021-00518-7.

Additional file 1. Table S1: Location information of sampling sites. Table S2. Environmental quality standards for surface water (GB3838-2002).

\section{Acknowledgements}

The authors would like to thank Yilun Gao, Xianyu Hou, Jin Tang, Wei Zhang from Chongqing University for sample collection and in situ parameters investigation.

\section{Authors' contributions}

JSG was responsible for the general design of the review; YS performed the majority of data evaluations and wrote the first draft of the manuscript. FF and YXJ supported data interpretation and drafted the manuscript; CCW, YJY and ZLC contributed on field sampling and data evaluations; YTF, TTL and MZ contributed on the laboratorial analysis. All authors read and approved the final manuscript. 


\section{Funding}

This work was founded by the EMR-rural project (No: 2019YFD1100500) from the National Key R\&D Program of China.

\section{Availability of data and materials}

The datasets used and/or analyzed during the current study are available from the corresponding author on reasonable request.

\section{Declarations}

\section{Ethics approval and consent to participate}

Not applicable.

\section{Consent for publication}

All authors agreed to publish the paper.

\section{Competing interests}

The authors declare that they have no competing interests.

Received: 21 April 2021 Accepted: 19 June 2021

Published online: 30 June 2021

\section{References}

1. Zhang W-L, Wu Y (2018) An analysis of the significance of protecting the village and town environment and its benefit in the new period. Acad Res 44:250-251

2. Wang H, Xu J, Liu X, Sheng L, Zhang D, Li L, Wang A (2018) Study on the pollution status and control measures for the livestock and poultry breeding industry in northeastern China. Environ Sci Pollut Res 25(5):4435-4445. https://doi.org/10.1007/s11356-017-0751-2

3. Chen Z, Shao Y, He M, Liang J, Jiang Y, Wang Y, Zhou M, Gong Z, Zhou X, Guo J, Fang F (2020) The EMR-rural project: key techniques and devices' development for rural environmental monitoring and remediation in China. Environ Sci Eur 32:11. https://doi.org/10.1186/s12302-020-00343-4

4. USDA (2021) Rural Utilities Service - Water \& Environmental Programs. https://www.rd.usda.gov/page/all-programs

5. Ahmed U, Mumtaz R, Anwar H, Mumtaz S (2020) Qamar AM (2020) Water quality monitoring: from conventional to emerging technologies (vol 20, pg 28. Water Sup 20(4):1580-1580. https://doi.org/10.2166/ws.2020.074

6. Chen Z, Zhu Z, Song J, Liao R, Wang Y, Luo X, Nie D, Lei Y, Shao Y, Yang W (2019) Linking biological toxicity and the spectral characteristics of contamination in seriously polluted urban rivers. Environ Sci Eur 31:174. https://doi.org/10.1186/s12302-019-0269-y

7. Shao Y, Xiao H, Di Paolo C, Deutschmann B, Brack W, Hollert H, Seiler TB (2019) Integrated zebrafish-based tests as an investigation strategy for water quality assessment. Water Res 150:252-260. https://doi.org/10. 1016/j.watres.2018.11.039

8. Bouaissa M, Ghalit M, Taupin JD, Khattabi JE, Gharibi E (2020) Assessment of groundwater quality in the Bokoya Massif (Central Rif, Northern Morocco) using several analytical techniques. Euro-Mediterr J Environ Integr 6(1):9. https://doi.org/10.1007/s41207-020-00208-5

9. Su H, Xu W, Hu X, Xu Y, Wen G, Cao Y (2021) Spatiotemporal variations and source tracking of antibiotics in an ecological aquaculture farm in Southern China. Sci Total Environ 763:143022. https://doi.org/10.1016/j. scitotenv.2020.143022

10. Wu C, Huang X, Witter JD, Spongberg AL, Wang K, Wang D, Liu J (2014) Occurrence of pharmaceuticals and personal care products and associated environmental risks in the central and lower Yangtze river, China. Ecotoxicol Environ Saf 106:19-26. https://doi.org/10.1016/j.ecoenv.2014. 04.029

11. Ministry of Ecology and Environment, PRC (2012) National Environmental Protection standards of the People's Republic of China (2012) in Water quality-Determination of total nitrogen-Alkaline potassium persulfate digestion UV spectrophotometric method. Ministry of Ecology and Environment, the People's Republic of China

12. Chen X, Wang Y, Sun T, Chen Y, Zhang M, Ye C (2021) Evaluation and prediction of water quality in the dammed estuaries and rivers of Taihu Lake. Environ Sci Pollut Res. https://doi.org/10.1007/s11356-020-12063-6
13. Li X-F, Ai J-Y, Lin C-H, Guan H-B (2018) Prediction model of dissolved oxygen in ponds based on ELM neural network. IOP Conf Ser: Earth Environ Sci 121:022003. https://doi.org/10.1088/1755-1315/121/2/022003

14. Jin Z, Ding S, Sun Q, Gao S, Fu Z, Gong M, Lin J, Wang D, Wang Y (2019) High resolution spatiotemporal sampling as a tool for comprehensive assessment of zinc mobility and pollution in sediments of a eutrophic lake. J Hazard Mater 364:182-191. https://doi.org/10.1016/j.jhazmat.2018. 09.067

15. Andriano KP, Taylor MS, Felix BA, Hamber EA, Daniels AU, Heller J (1995) Technical note: bioluminescent bacterial test for acute toxicity: the effect of pH and buffer solutions. J Appl Biomater 6(2):145-146. https://doi.org/ 10.1002/jab.770060210

16. Ministry of Ecology and Environment, PRC (2002) Environmental quality standers for surface water. Ministry of Ecology and Environment, the People's Republic of China

17. Huang G-Q, Wu L, Li Y-X, Zhang W-F, Zhang F-S (2013) Development situation and suggestions on nitrogen fertilizer industry in China. Mod Chem Ind 33(10):5-9

18. Liu B, Wang X, Ma L, Chadwick D, Chen X (2021) Combined applications of organic and synthetic nitrogen fertilizers for improving crop yield and reducing reactive nitrogen losses from China's vegetable systems: a meta-analysis. Environ Pollut 269:1 16143. https://doi.org/10.1016/j. envpol.2020.116143

19. Zhao Z-L, Li W-W, Wang F, Zhang Y-Q (2018) Using of hydrated lime water as a novel degumming agent of silk and sericin recycling from wastewater. J Clean Prod 172:2090-2096. https://doi.org/10.1016/j.jclepro.2017.11. 213

20. Liu W, Yao H, Xu W, Liu G, Wang X, Tu Y, Shi P, Yu N, Li A, Wei S (2020) Suspect screening and risk assessment of pollutants in the wastewater from a chemical industry park in China. Environ Pollut 263:114493. https://doi. org/10.1016/j.envpol.2020.114493

21. Chen C, Li TT, Zou WB, Chen SS, Zhang K, Ma LM (2020) Spatial distribution and sources of organochlorine pesticides in surface waters of Shanghai. China SN Appl Sci 2:1739

22. Tsygankov V-Y (2019) Organochlorine pesticides in marine ecosystems of the Far Eastern Seas of Russia (2000-2017). Water Res 161:43-53. https:// doi.org/10.1016/j.watres.2019.05.103

23. Correia TG, Narcizo AM, Bianchini A, Moreira RG (2010) Aluminum as an endocrine disruptor in female Nile tilapia (Oreochromis niloticus). Comp Biochem Phys C 151(4):461-466. https://doi.org/10.1016/j.cbpc.2010.02. 002

24. Mondal S, Subramaniam C (2020) Xenobiotic contamination of water by plastics and pesticides revealed through real-time, ultrasensitive, and reliable surface-enhanced Raman scattering. ACS Sustain Chem Eng 8(20):7639-7648. https://doi.org/10.1021/acssuschemeng.0c00902

25. Briceno G, Lamilla C, Leiva B, Levio M, Donoso-Pinol P, Schalchli H, Gallardo F, Diez MC (2020) Pesticide-tolerant bacteria isolated from a biopurification system to remove commonly used pesticides to protect water resources. PLoS ONE 15(6):20. https://doi.org/10.1371/journal.pone. 0234865

26. Tsui MTK, Chu LM (2003) Aquatic toxicity of glyphosate-based formulations: comparison between different organisms and the effects of environmental factors. Chemosphere 52(7):1189-1197. https://doi.org/ 10.1016/S0045-6535(03)00306-0

27. Sun Q, Liu Z (2020) Impact of tourism activities on water pollution in the West Lake Basin (Hangzhou, China). Open Geosci 12(1):1302-1308. https://doi.org/10.1515/geo-2020-0119

28. Garcés-Ordóñez O, Espinosa Díaz LF, Pereira Cardoso R, Costa Muniz M (2020) The impact of tourism on marine litter pollution on Santa Marta beaches Colombian Caribbean. Mar Pollut Bull 160:111558. https://doi. org/10.1016/j.marpolbul.2020.111558

29. Katircioglu S, Saqib N, Katircioglu S, Kilinc CC, Gul H (2020) Estimating the effects of tourism growth on emission pollutants: empirical evidence from a small island. Cyprus Air Qual Atmos Hlth 13(4):391-397. https:// doi.org/10.1007/s11869-020-00803-z

30. Saeck EA, O'Brien KR, Weber TR, Burford MA (2013) Changes to chronic nitrogen loading from sewage discharges modify standing stocks of coastal phytoplankton. Mar Pollut Bull 71(1-2):159-167. https://doi.org/ 10.1016/j.marpolbul.2013.03.020 
31. Välitalo P, Kruglova A, Mikola A, Vahala R (2017) Toxicological impacts of antibiotics on aquatic micro-organisms: a mini-review. Int J Hyg Envir Heal 220(3):558-569. https://doi.org/10.1016/j.jheh.2017.02.003

32. Wang X, Ryu D, Houtkooper RH, Auwerx J (2015) Antibiotic use and abuse: a threat to mitochondria and chloroplasts with impact on research, health, and environment. BioEssays 37(10):1045-1053. https:// doi.org/10.1002/bies.201500071

33. Castaldo G, Delahaut V, Slootmaekers B, Bervoets L, Town RM, Blust R, De Boeck G (2020) A comparative study on the effects of three different metals (Cu, Zn and Cd) at similar toxicity levels in common carp. Cyprinus carpio J Appl Toxicol. https://doi.org/10.1002/jat.4131

34. Li J, Liu Y, Zuo R, Teng Y, Ai Y, Yang J (2018) Influences of dissolved humic acid on Zn bioavailability and its consequences for thyroid toxicity. Ecotoxicol Environ Saf 166:132-137. https://doi.org/10.1016/j.ecoenv.2018. 09.051

35. Gao L, Li R, Liang Z, Wu Q, Yang Z, Li M, Chen J, Hou L (2020) Mobilization mechanisms and toxicity risk of sediment trace metals ( $\mathrm{Cu}, \mathrm{Zn}, \mathrm{Ni}$, and
$\mathrm{Pb}$ ) based on diffusive gradients in thin films: A case study in the Xizhi River basin South China. J Hazard Mater. https://doi.org/10.1016/j.jhazm at.2020.124590

36. Tkaczyk A, Mitrowska K, Posyniak A (2020) Synthetic organic dyes as contaminants of the aquatic environment and their implications for ecosystems: a review. Sci Total Environ 717:19. https://doi.org/10.1016/j. scitotenv.2020.137222

37. Nesme T, Withers PJA (2016) Sustainable strategies towards a phosphorus circular economy. Nutr Cycl Agroecosystems 104(3):259-264. https://doi. org/10.1007/s10705-016-9774-1

\section{Publisher's Note}

Springer Nature remains neutral with regard to jurisdictional claims in published maps and institutional affiliations.

\section{Submit your manuscript to a SpringerOpen ${ }^{\circ}$ journal and benefit from:}

- Convenient online submission

- Rigorous peer review

- Open access: articles freely available online

- High visibility within the field

- Retaining the copyright to your article

Submit your next manuscript at $\boldsymbol{\nabla}$ springeropen.com 